\title{
Interactions of Cationic and Neutral Molybdenum Complexes with $\beta$-Cyclodextrin Host Molecules
}

\author{
Sérgio Lima, ${ }^{\dagger}$ I sabel S. Gonçalves, ${ }^{*, t, \ddagger}$ Paulo Ribeiro-Claro, ${ }^{\dagger, \S}$ Martyn Pillinger ${ }^{\dagger}$ \\ André D. Lopes, ${ }^{\dagger}$ Paula Ferreira, ${ }^{\dagger} \mathrm{J}$ osé J . C. Teixeira-Dias, ${ }^{*},{ }^{\dagger} \mathrm{J}$ oão Rocha, ${ }^{\dagger}$ and \\ Carlos C. Romãol \\ Department of Chemistry, University of Aveiro, Campus de Santiago, \\ 3810-193 Aveiro, Portugal, Química-F ísica Molecular, Faculdade de Ciências e Tecnol ogia, \\ Universidade de Coimbra, 3004-353 Coi mbra, Portugal, and Instituto de Tecnol ogia Química e \\ Biológica, Quinta do Marquês, EAN, Apt 127, 2781-901 Oeiras, Portugal
}

Received December 27, 2000

\begin{abstract}
The inclusion compounds formed between $\beta$-cyclodextrin ( $\beta$-CD) and the tetrafluoroborate salts $\left[\mathrm{Cp}^{\prime} \mathrm{Mo}\left(\eta^{4}-\mathrm{C}_{6} \mathrm{H}_{8}\right)(\mathrm{CO})_{2}\right]\left[\mathrm{BF}_{4}\right]$ and the neutral derivatives $\mathrm{C} \mathrm{p}^{\prime} \mathrm{Mo}\left(\eta^{3}-\mathrm{C}_{6} \mathrm{H}_{7}\right)(\mathrm{CO})_{2}\left[\mathrm{Cp}^{\prime}=\right.$ $\mathrm{Cp}\left(\eta^{5}-\mathrm{C}_{5} \mathrm{H}_{5}\right)$, Ind $\left.\left(\eta^{5}-\mathrm{C}_{9} \mathrm{H}_{7}\right)\right]$ were studied by means of elemental analysis, FTIR spectroscopy, thermogravimetric analysis (TGA), powder X-ray diffraction (XRD), and magic-angle spinning (MAS) NMR $\left({ }^{13} \mathrm{C},{ }^{11} \mathrm{~B}\right)$. Additional information concerning the possible structure of the inclusion compounds was obtained from ab initio calculations using a two-layer approximation. The cationic and neutral $\eta^{5}$-cyclopentadienyl analogues form stable two-to-one (hostto-guest) channel-type inclusion compounds in a crystalline state. By contrast, the $\eta^{5}$-indenyl analogues form only weak complexes with $\beta$-CD and it is evident that the organometallic guests are easily liberated from the host cavities. The ab initio calculations revealed that the steric hindrance arising from the presence of the indenyl ligand is a possible explanation for the experimentally observed lower stability of these compounds.
\end{abstract}

\section{Introduction}

The past few years have witnessed an increasing effort toward the modification of steric, electronic, and other properties of well-known organometallic first sphere ligands as a means of achieving tuneable reactivity control of their complexes. ${ }^{1}$ An interesting extension of this concept is theintroduction of a second sphere ligand noncovalently attached to the first sphere ligand. This situation arises, for example, when an organometallic molecule (the guest) is encapsulated within a supramolecular host. Cyclodextrins (CD) are a group of macrocyclic oligosaccharides that are well-known to form such inclusion complexes. ${ }^{2}$ They selectively bind a variety of metalloorganic and organometallic molecules bearing hydrophobic ligands such as cyclopentadienyl $(C p)$ and $\eta^{6}$-arene groups. ${ }^{3}$ Second sphere coordination adducts have been reported with ferrocene and its derivatives, ${ }^{4}$ titanocene dihalides, ${ }^{5}$ aromatic ruthenium complexes, ${ }^{6}$ mixed sandwich complexes such as $\left[\left(\eta^{5}-\mathrm{C}_{5} \mathrm{H}_{5}\right) \mathrm{Fe}\left(\eta^{6}-\mathrm{C}_{6} \mathrm{H}_{6}\right)\right]\left[\mathrm{PF}_{6}\right],{ }^{7}$ and half-sandwich complexes such as $\mathrm{CpFe}(\mathrm{CO})_{2} \mathrm{X}(\mathrm{X}=\mathrm{Cl}, \mathrm{Me})_{1},{ }^{8,9} \mathrm{CpMn}$ $(\mathrm{CO})_{3},{ }^{10}\left(\eta^{6}-\mathrm{C}_{6} \mathrm{H}_{6}\right) \mathrm{Cr}(\mathrm{CO})_{3},{ }^{11}$ and $\mathrm{Cp}^{\prime} \mathrm{Mo}\left(\eta^{3}-\mathrm{C}_{3} \mathrm{H}_{5}\right)(\mathrm{CO})_{2}$ $\left(\mathrm{C} \mathrm{p}^{\prime}=\mathrm{Cp}\right.$, Ind) ${ }^{12}$

\footnotetext{
+ University of Aveiro.

‡ E-mail: igoncalves@dq.ua.pt. Fax: +351-234-370084.

$\S$ Universidade de Coimbra.

"Instituto de Tecnologia Química e Biológica.

(1) Romão, C. C. Appl. Organomet. Chem. 2000, 14, 539 and references therein.

(2) (a) Szejtli, J. Chem. Rev. 1998, 98, 1743. (b) Saenger, W. Angew. Chem., Int. Ed. Engl. 1980, 19, 344.

(3) Fenyvesi, E.; Szente, L.; Russel, N. R.; McNamara, M. In Comprehensive Supramolecular Chemistry; Atwood, J. L., Davies, J . E. D., MacNicol, D. D., Vögtle, F., Lehn, J .-M., Szejtli, J ., Osa, T., Eds.; Pergamon: Oxford, 1996; Vol. 3, Chapter 10.
}

Half-sandwich complexes encapsulated within CDs have been shown to exhibit markedly different physical and chemical properties compared to those of the bulk material, for example, in their nonlinear optical properties ${ }^{13}$ and ligand substitution/insertion reactions. ${ }^{8}$ Also, metal locenes such as $\mathrm{Cp}_{2} \mathrm{MCl}_{2}(\mathrm{M}=\mathrm{Ti}, \mathrm{Mo})$ are potent organometallic antitumor agents ${ }^{14}$ and $C D$ inclusion compounds are interesting for pharmaceutical use. ${ }^{5}$ The driving forces for the inclusion complexation of $C D$ with

(4) Breslow, R.; Trainor, G.; Ueno, A. J . Am. Chem. Soc. 1983, 105, 2739. (b) Harada, A.; Takahashi, S. J. Chem. Soc., Chem. Commun. 1984, 645. (c) Harada, A.; Hu, Y.; Yamamoto, S.; Takahashi, S. J. Chem. Soc., Dalton Trans. 1988, 729. (d) Odagaki, Y.; Hirotsu, K.; Higuchi, T.; Harada, A.; Takahashi, S. J . Chem. Soc., Perkin Trans. I 1990, 1230. (e) Imashiro, F.; Kuwahara, D.; Kitazaki, N.; Terao, T Magn. Reson. Chem. 1992, 30, 796. (f) Kuwahara, D.; Imashiro, F.; Terao, T. Chem. Phys. Lett. 1993, 204, 533. (g) Bakhtiar, R.; Kaifer, A. E. Rapid Commun. Mass Spectrom. 1998, 12, 111. (h) Ferreira, P.; Gonçalves, I. S.; Pillinger, M.; Rocha, J .; Santos, P.; Teixeira-Dias, J . J. C. Organometallics 2000, 19, 1455.

(5) Turel, I.; Demsar, A.; Kosmrlj, J . J . Mol. Recognit. Macro. Chem. 1999, 35, 595.

(6) Meister, G.; Stoeckli-Evans, H.; Süss-Fink, G. J . Organomet. Chem. 1993, 453, 249.

(7) (a) Klingert, B.; Rihs, G. Organometallics 1990, 9, 1335. (b) Klingert, B.; Rihs, G. J . Inclusion Phenom. 1991, 10, 255. (c) Klingert, B.; Rihs, G. J . Chem. Soc., Dalton Trans. 1991, 2749.

(8) (a) Shimada, M.; Harada, A.; Takahashi, S. J. Chem. Soc., Chem. Commun. 1991, 263. (b) Patel, P. P.; Welker, M. E. J . Organomet. Chem. 1997, 547, 103.

(9) Díaz, C.; Arancibia, A. J . Inclusion Phenom. Mol. Recognit. 1998, 30, 127.

(10) Song, L.; Meng, Q.; You, X. J . Organomet. Chem. 1995, 498, C1.

(11) Harada, A.; Saeki, K.; Takahashi, S. Organometallics 1989, 8, 730

(12) Braga, S. S.; Goncalves, I. S.; Lopes, A. D.; Pillinger, M.; Rocha, J .; Romão, C. C.; Teixeira-Dias, J . J . C. J . Chem. Soc., Dalton Trans. 2000, 2964.

(13) Eaton, D. F.; Anderson, A. G.; Tam, W.; Wang, Y.J . Am. Chem. Soc. 1987, 109, 1886. 


\section{Scheme 1}

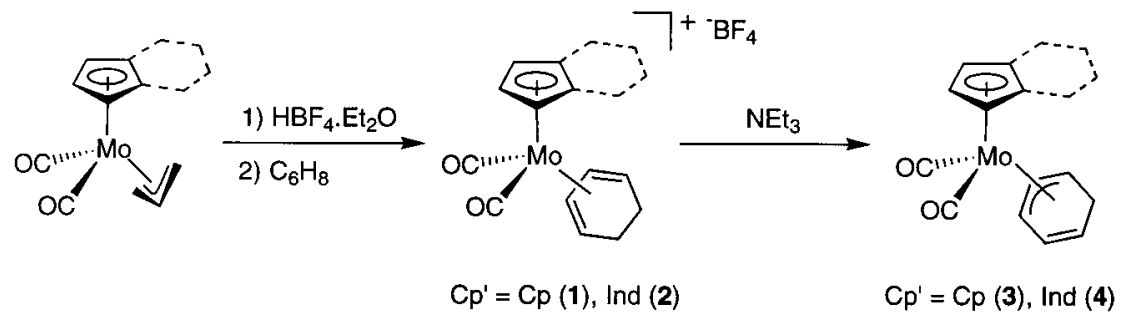

substrates are attributed to several factors, such as van der Waals forces, hydrophobic interactions, el ectronic effects, and steric factors. ${ }^{15,16}$ Theory has been extensively applied to the problem of predicting the formation and geometry of CD-guest inclusion systems. In this paper, we describe a combined experimental and theoretical study of the interaction of $\beta$-cyclodextrin with the dicarbonyl molybdenum complexes $\mathrm{C} p^{\prime} \mathrm{Mo}\left(\eta^{3}-\mathrm{C}_{6} \mathrm{H}_{7}\right)$ $(\mathrm{CO})_{2}$ and $\left[\mathrm{Cp}^{\prime} \mathrm{Mo}\left(\eta^{4}-\mathrm{C}_{6} \mathrm{H}_{8}\right)(\mathrm{CO})_{2}\right]\left[\mathrm{BF}_{4}\right]\left(\mathrm{Cp}^{\prime}=\mathrm{Cp}\right.$, Ind). Complexes such as these are important in stereoselective organic syntheses. ${ }^{17-19}$ The present work aims to rationalize the contrasting inclusion complexation behaviors observed.

\section{Results and Discussion}

1. Preparation of the Diene and Allylmolybdenum Complexes. The chemistry of diene and dienylMo complexes has been intensively investigated and has considerable potential in organic synthesis. Diene complexes have played an important role in activation/ functionalization of the unsaturated ligands. This chemistry is well-known for the fragment $\left[\mathrm{Cp}^{\prime} \mathrm{Mo}(\mathrm{CO})_{2}\right]^{+}$ $\left[\mathrm{Cp}^{\prime}=\mathrm{Cp}, \eta^{5}-\mathrm{C}_{5} \mathrm{Me}_{5}\left(\mathrm{C} \mathrm{p}^{*}\right)\right.$, Ind], including aspects such as the regiospecificity of nucleophilic attack at the 18el ectron cations [ $\left.\mathrm{Cp} \mathrm{p}^{\prime} \mathrm{Mo}\left(\eta^{4} \text {-diene)(CO }\right)_{2}\right]^{+}, 17$ the formation of diene compl exes from $\mathrm{Cp}^{\prime} \mathrm{Mo}\left(\eta^{3}\right.$-allyl $)(\mathrm{CO})_{2} \mathrm{com}$ plexes, ${ }^{18}$ and the deprotonation of [C $\mathrm{p}^{\prime} \mathrm{Mo}\left(\eta^{4}\right.$-diene)$\left.(\mathrm{CO})_{2}\right]^{+}$to give allylic species $\mathrm{C} p^{\prime} \mathrm{Mo}\left(\eta^{3}\right.$-allyl $)(\mathrm{CO})_{2}{ }^{19}$

The well-known cation in $\left[\mathrm{CpM} \mathrm{o}\left(\eta^{4}-\mathrm{C}_{6} \mathrm{H}_{8}\right)\left(\mathrm{CO}_{2}\right]\left[\mathrm{BF}_{4}\right]\right.$ (1) was prepared as described recently by some of us. ${ }^{199}$

(14) (a) Kuo, L. Y.; Kanatzidis, M. G.; Sabat, M.; Tipton, A. L.; Marks, T. J J . Am. Chem. Soc. 1991, 113, 9027. (b) Harding, M. M. Mokdsi, G.; Mackay, J . P.; Prodigalidad, M.; Lucas, S. W. Inorg. Chem. 1998, 37, 2432

(15) Connors, K. A. Chem. Rev. 1997, 97, 1325.

(16) Szejtli, J. In Comprehensive Supramol ecular Chemistry; Atwood, J . L., Davies, J . E. D., Macnicol, D. D., Vögtle, F., Lehn, J.-M., Szejtli, j ., Osa, T., Eds.; Pergamon: Oxford, 1996; Vol. 3, Chapter 5.

(17) (a) Kane-Maguire, L. A. P.; Honig, E. D.; Sweigart, D. A. Chem Rev. 1984, 84, 525. (b) Pearson, A. J .; Khan, Md. N. I.; Clardy, J . C.; Cun-heng, H. J . Am. Chem. Soc. 1985, 107, 2748. (c) Green, M. Greenfield, S.; Kersting, M. J. Chem. Soc., Chem. Commun. 1985, 18. (d) Pearson, A. J . Adv. Met. Org. Chem. 1989, 1, 1. (e) Pearson, A. J." Blystone, S. L.; Nar, H.; Pinkerton, A. A.; Roden, B. A.; Yoon, J . J . Am. Chem. Soc. 1989, 111, 134.

(18) Faller, J. W.; Murray, H. H.; White, D. L.; Chao, K. H. Organometallics 1983, 2, 400 .

(19) (a) Baxter, J. S.; Green, M.; Lee, T. V. J . Chem. Soc., Chem. Commun. 1989, 1595. (b) Feldman, J .; Calabrese, J . C. J . Chem. Soc., Chem. Commun. 1991, 134. (c) Wang, S.-H.; Cheng, Y.-C.; Lee, G.-H.; Peng, S.-M.; Liu, R.-S. Organometallics 1993, 12, 3282. (d) Wang, T. F.; Lee, M.-C.; Wen, Y.-S. J. Organomet. Chem. 1994, 483, 91. (e) Félix, V.; Calhorda, M. J .; Drew, M. G. B.; Gonçalves, I. S.; Romão, C. C. Inorg. Chim. Acta 1998, 275-276, 263. (f) Ascenso, J . R.; Azevedo, C. G.; Gonçalves, I. S.; Herdtweck, E.; Moreno, D. S.; Romão, C. C.; Zühlke, J. Organometallics 1994, 13, 429. (g) Ascenso, J. R.; de Azevedo, C. G.; Goncalves, I. S.; Herdtweck, E.; Moreno, D. S. Pessanha, M.; Romão, C. C. Organometallics 1995, 14, 3901. (h) Almeida, J. M.; Gonçalves, I. S.; Romão, C. C. An. Quím. Int. Ed. 1997, 93, 8. (i) Benyunes, S. A.; Binelli, A.; Green, M.; Grimshire, M. J .J. Chem. Soc., Dalton Trans. 1991, 895.
This involves the protonation of $\mathrm{Cp}^{\prime} \mathrm{Mo}\left(\eta^{3}-\mathrm{C}_{3} \mathrm{H}_{5}\right)(\mathrm{CO})_{2}$ with $\mathrm{HBF}_{4} \cdot \mathrm{Et}_{2} \mathrm{O}$ in $\mathrm{CH}_{2} \mathrm{Cl}_{2}$ to give a red solution of $\left[\mathrm{Cp}^{\prime} \mathrm{Mo}\left(\eta^{2}-\mathrm{C}_{3} \mathrm{H}_{6}\right)(\mathrm{CO})_{2}\left(\mathrm{FBF}_{3}\right)\right]{ }^{20}$ Addition of 1,3-cyclohexadiene to this solution leads to the rapid formation of $\mathbf{1}$. We have now extended this to the preparation of the indenyl analogue $\left[\mathrm{IndMO}\left(\eta^{4}-\mathrm{C}_{6} \mathrm{H}_{8}\right)\left(\mathrm{CO}_{2}\right]\left[\mathrm{BF}_{4}\right]\right.$ (2) (Scheme 1). Compound $\mathbf{2}$ was originally prepared by Bottril and Green by reaction of the diene with [I ndM o$(\mathrm{CO})_{2}\left(\mathrm{NCMe}_{2}\right]\left[\mathrm{BF}_{4}\right]{ }^{21}$ Neither $\mathbf{1}$ nor $\mathbf{2}$ are very air sensitive, decomposing within a few hours when exposed to air. They are soluble in dichloromethane, ethanol, and acetone and precipitate from the reaction mixtures upon addition of diethyl ether, hexane, or pentane. They are slightly soluble in water.

Treatment of $\mathbf{1}$ and $\mathbf{2}$ with triethylamine in $\mathrm{CH}_{2} \mathrm{Cl}_{2}$ gives the neutral complexes $\mathrm{C} p^{\prime} \mathrm{Mo}\left(\eta^{3}-\mathrm{C}_{6} \mathrm{H}_{7}\right)(\mathrm{CO})_{2}$ $\left[C p^{\prime}=C p(3),{ }^{17 d, 19 c, d, 9 ~ I n d ~(4)] ~(S c h e m e ~ 1) . ~ T h i s ~ p r e p a r a-~}\right.$ tion is advantageous over the one originally reported for $\mathbf{4}$, which involved the treatment of $\mathbf{2}$ with (dppe)Pt$(\mathrm{OMe})_{2}$ [dppe $=1$ 1,2-bis(diphenyl phosphino)ethane]. ${ }^{19 b}$ The ${ }^{1} \mathrm{H}$ NMR spectrum of $\mathbf{4}$ exhibits a characteristic pattern for the resonances of the $\eta^{5}$-indenyl rather than the ring-slipped $\eta^{3}$-indenyl, i.e., one signal for the $\mathrm{C}_{6}$ ring protons $\left(\mathrm{H}_{5-8}\right)$ at ca. $\delta 7.05 \mathrm{ppm}$, two signals at ca. $\delta 6.01$ and $5.87 \mathrm{ppm}\left(\mathrm{H}_{1}\right.$ and $\left.\mathrm{H}_{3}\right)$, and a triplet centered at $\delta 5.53 \mathrm{ppm}\left(\mathrm{H}_{2}\right){ }^{22}$ The ${ }^{13} \mathrm{C} \mathrm{NMR}$ spectrum also confirms the presence of $\eta^{5}-\mathrm{C}_{9} \mathrm{H}_{7}$ as the chemical shifts for the indenyl junction carbon atoms $\mathrm{C}_{4 / 9}\left({ }^{13} \mathrm{C}\right.$ CP MAS NMR: $\delta 111.7 \mathrm{ppm}$ ) are at higher field than would be expected for $\eta^{3}-\mathrm{C}_{9} \mathrm{H}_{7} .{ }^{19 \mathrm{~h}} \mathrm{In}$ conclusion, the ring slippage of the $\mathrm{C}_{6}$ ring, $\eta^{5}-\mathrm{C}_{6} \mathrm{H}_{7} \rightarrow \eta^{3}-\mathrm{C}_{6} \mathrm{H}_{7}$, is easier than that of the indenyl system, $\eta^{5}-\mathrm{C}_{9} \mathrm{H}_{7} \rightarrow \eta^{3}-\mathrm{C}_{9} \mathrm{H}_{7}$, as is also the case for the tropylium derivative $\left(\eta^{5}-\mathrm{C}_{9} \mathrm{H}_{7}\right) \mathrm{Mo}\left(\eta^{3}-\mathrm{C}_{7} \mathrm{H}_{7}\right)$ $(\mathrm{CO})_{2} \cdot{ }^{19 \mathrm{~h}}$ In the IR spectrum, two bands are observed in the $v(\mathrm{CO})$ stretching region consistent with the existence of only one isomer in the solid state (Table 1 ). Complexes $\mathbf{3}$ and $\mathbf{4}$ are soluble in dichloromethane, acetone, diethyl ether, hexane, or pentane and insoluble in water. They are stable at room temperature and can be handled in air for brief periods of time (several minutes).

2. Preparation and Characterization of Inclusion Compounds. Mixing of a warm saturated solution of $\beta$-CD in water with a solution of $\left[C p^{\prime} \mathrm{Mo}\left(\eta^{4}-\mathrm{C}_{6} \mathrm{H}_{8}\right)\right.$ $\left.(\mathrm{CO})_{2}\right]\left[\mathrm{BF}_{4}\right]\left[\mathrm{Cp}^{\prime}=\mathrm{Cp}(\mathbf{1})\right.$, Ind (2)] or $\mathrm{C} p^{\prime} \mathrm{Mo}\left(\eta^{3}-\mathrm{C}_{6} \mathrm{H}_{7}\right)-$ $(\mathrm{CO})_{2}\left[\mathrm{Cp}^{\prime}=\mathrm{Cp}(3)\right.$, Ind (4)] in dichloromethane resulted in slow formation of a pale yellow precipitate at the interface between the two sol utions. The products were isolated by filtration and rinsed with dichloromethane

(20) Markham, J .; Menard, K.; Cutler, A. Inorg. Chem. 1985, 24 , 1581

(21) Bottril, M.; Green, M.J . Chem. Soc., Dalton Trans. 1977, 2365.

(22) Ascenso, J . R.; Gonçalves, I. S.; Herdtweck, E.; Romão, C. C. J . Organomet. Chem. 1996, 508, 169. 
Table 1. IR Data $\left(\mathrm{cm}^{-1}\right)$ for Included and Nonincluded Dicarbonyl Complexes

\begin{tabular}{|c|c|c|c|c|}
\hline comp & & $v(\mathrm{CO})^{\mathrm{a}}$ & $\Delta v(\mathrm{CO})$ & $v(\mathrm{CO})^{\mathrm{b}}$ \\
\hline $\begin{array}{l}{\left[\mathrm{CpMo}\left(\eta^{4}-\mathrm{C}_{6} \mathrm{H}_{8}\right)(\mathrm{CO})_{2}\right]\left[\mathrm{BF}_{4}\right]^{\mathrm{c}}} \\
\beta-\mathrm{CD} /\left[\mathrm{CpM} \mathrm{O}\left(\eta^{4}-\mathrm{C}_{6} \mathrm{H}_{8}\right)-\right. \\
\left.(\mathrm{CO})_{2}\right]\left[\mathrm{BF}_{4}\right]\end{array}$ & $\begin{array}{l}1 \\
\text { la }\end{array}$ & $\begin{array}{l}\text { 1998, } 1937 \\
2017,1963\end{array}$ & 19, 26 & 199 \\
\hline $\begin{array}{l}\left.\mathrm{O}\left(\eta^{4}-\mathrm{C}_{6} \mathrm{H}_{8}\right)(\mathrm{CO})_{2}\right]\left[\mathrm{BF}_{4}\right] \\
{\left[\operatorname{lndMO}^{4}\left(\eta^{4}-\mathrm{C}_{6} \mathrm{H}_{8}\right)-\right.} \\
]\left[\mathrm{BF}_{4}\right]\end{array}$ & $\begin{array}{l}2 \\
2 a\end{array}$ & $\begin{array}{l}1999 \\
2044\end{array}$ & & 1997 \\
\hline $\begin{array}{l}\mathrm{CpMo}\left(\eta^{3}-\mathrm{C}_{6} \mathrm{H}_{7}\right)(\mathrm{CO})_{2}{ }^{\mathrm{d}} \\
\beta-\mathrm{CD} / \mathrm{CpMo}\left(\eta^{3}-\mathrm{C}_{6} \mathrm{H}_{7}\right)(\mathrm{CO})_{2}\end{array}$ & $\begin{array}{l}3 \\
3 a\end{array}$ & & 13, 37 & 1936,18 \\
\hline $\begin{array}{l}\text { IndM } \mathrm{o}\left(\eta^{3}-\mathrm{C}_{6} \mathrm{H}_{7}\right)(\mathrm{CO})_{2} \\
\beta-\mathrm{CD} / \mathrm{IndMo}\left(\eta^{3}-\mathrm{C}_{6} \mathrm{H}_{7}\right)(\mathrm{CO})_{2}\end{array}$ & $\begin{array}{l}4 \\
4 a\end{array}$ & $\begin{array}{l}1933,1839 \\
1940,1869\end{array}$ & 7,30 & \\
\hline
\end{tabular}

a Solid-state $\mathrm{KBr}$ IR spectra $\left(v_{\text {symm }}, v_{\text {asym }}\right) .{ }^{\mathrm{b}} \mathrm{Ab}$ initio scaled harmonic wavenumbers $\left(v_{\text {sym }}, v_{\text {asym }}\right)$. c Solution IR for $\mathbf{l}\left(\mathrm{CH}_{2} \mathrm{Cl}_{2}\right.$, $\left.\mathrm{cm}^{-1}\right)$ : 2016, 1961. d Solution IR for $3\left(\mathrm{CH}_{2} \mathrm{Cl}_{2}, \mathrm{~cm}^{-1}\right)$ : 1937, 1856.

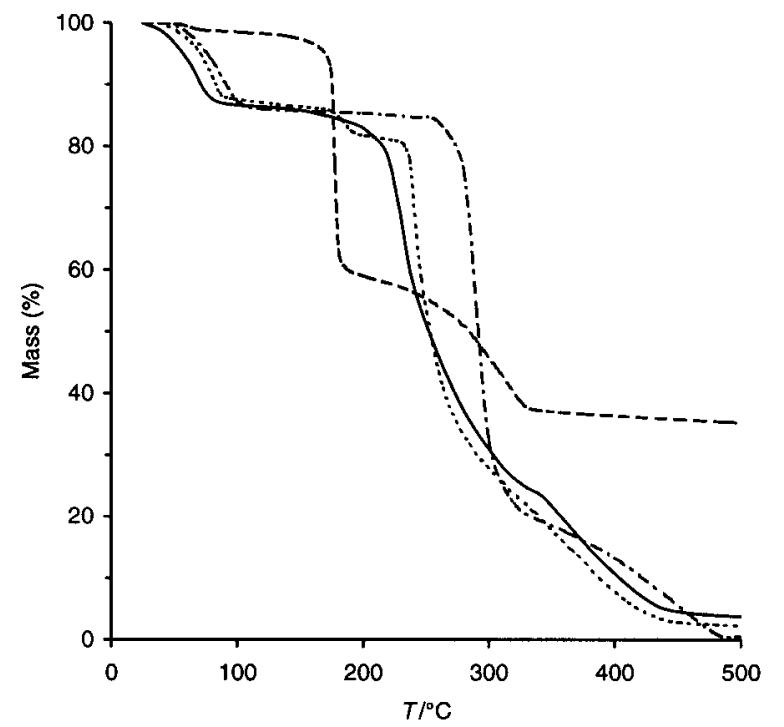

Figure 1. TGA of $\beta-\mathrm{CD} /\left[\mathrm{CpMO}\left(\eta^{4}-\mathrm{C}_{6} \mathrm{H}_{8}\right)(\mathrm{CO})_{2}\right]\left[\mathrm{BF}_{4}\right]$ (1a) $(-),\left[\mathrm{CpM} \mathrm{o}\left(\eta^{4}-\mathrm{C}_{6} \mathrm{H}_{8}\right)\left(\mathrm{CO}_{2}\right]\left[\mathrm{BF}_{4}\right](\mathbf{1})(---)\right.$, pristine $\beta-\mathrm{CD}$ hydrate (- - - ), and a physical mixture of $\beta$-CD and $\mathbf{l}$ in a $2: 1$ molar ratio (…...).

to remove the unchanged molybdenum complexes. Finally, the products were washed with water to remove any remaining pristine cyclodextrin hydrate and vacuumdried. Elemental analyses indicated that compounds $\beta-\mathrm{CD} /\left[\mathrm{CpMo}\left(\eta^{4}-\mathrm{C}_{6} \mathrm{H}_{8}\right)\left(\mathrm{CO}_{2}\right)_{2}\left[\mathrm{BF}_{4}\right](\mathbf{l a})\right.$ and $\mathrm{CD} / \mathrm{CpM}$ o $\left(\eta^{3}-\right.$ $\left.\mathrm{C}_{6} \mathrm{H}_{7}\right)(\mathrm{CO})_{2}$ (3a) were stoichiometric 2:1 (host to guest) inclusion compounds. The washing steps did not liberate the included guests from the cyclodextrin cavities. In the cases of $\beta-\mathrm{CD} /\left[\mathrm{I}\right.$ ndM o $\left(\eta^{4}-\mathrm{C}_{6} \mathrm{H}_{8}\right)\left(\mathrm{CO}_{2}\right]\left[\mathrm{BF}_{4}\right](\mathbf{2 a})$ and $\beta$-CD/IndMo $\left(\eta^{3}-\mathrm{C}_{6} \mathrm{H}_{7}\right)(\mathrm{CO})_{2}$ (4a), the corresponding inclusion compounds could not be obtained in an analytically pure form (see Experimental Section). This was attributed to liberation of a proportion of the included complexes by the washing steps. Compounds $\mathbf{1 a - 4 a}$ are insoluble in water and air sensitive. After exposure to air for approximately $8 \mathrm{~h}$, the cationic compl exes change to blue and the neutral compl exes change to green. The products were further characterized in the solid state by powder XRD, MAS NMR $\left({ }^{13} \mathrm{C},{ }^{11} \mathrm{~B}\right), \mathrm{TGA}$, and FTIR spectroscopy.

Thermogravimetric Analysis. Figure 1 shows the results of thermogravimetric analysis of $\beta-\mathrm{CD} /[\mathrm{CpM}$ $\left.\left(\eta^{4}-\mathrm{C}_{6} \mathrm{H}_{8}\right)(\mathrm{CO})_{2}\right]\left[\mathrm{BF}_{4}\right](\mathbf{l a})$, the organometallic [CpM o$\left.\left(\eta^{4}-\mathrm{C}_{6} \mathrm{H}_{8}\right)(\mathrm{CO})_{2}\right]\left[\mathrm{BF}_{4}\right](\mathbf{1})$, pristine $\beta$-CD hydrate, and a physical mixture of $\beta$-CD and 1 in a 2:1 molar ratio. TGA of $\beta$-CD shows loss of hydrated water up to $130{ }^{\circ} \mathrm{C}$
Table 2. TGA and NMR Data $\left({ }^{11} B\right.$ and ${ }^{13} \mathrm{C}$ MAS NMR) for Included and Nonincluded Dicarbonyl Complexes

\begin{tabular}{|c|c|c|c|c|}
\hline complex & & $\mathrm{T}$ a $/{ }^{\circ} \mathrm{C}$ & $\begin{array}{c}{ }^{11} \mathrm{~B} \\
(\mathrm{ppm})^{\mathrm{b}}\end{array}$ & $\begin{array}{c}{ }^{13} \mathrm{C} \\
\text { (CO) } \\
\text { (ppm }\end{array}$ \\
\hline 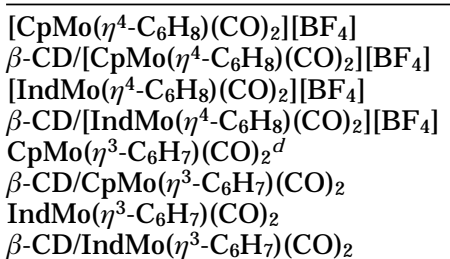 & $\begin{array}{l}1 \\
1 \mathbf{a} \\
2 \\
2 \mathrm{a} \\
3 \\
3 \mathrm{a} \\
4 \\
4 \mathbf{a}\end{array}$ & $\begin{array}{l}176 \\
230 \\
140 \\
234 \\
115 \\
231 \\
117 \\
225\end{array}$ & $\begin{array}{l}-1.4(130) \\
-1.5(50) \\
-1.0(262) \\
-1.7(225)\end{array}$ & $\begin{array}{l}229.7 \\
222.2 \\
229 . \mathrm{C} \\
\mathrm{n} / \mathrm{o}^{\mathrm{c}} \\
237 . \mathrm{C} \\
\mathrm{n} / \mathrm{o} \\
240.4 \\
\mathrm{n} / \mathrm{o}\end{array}$ \\
\hline
\end{tabular}

a $\mathrm{T}=$ decomposition temperature (peak maximum in the differential thermogravimetric profile). ${ }^{b}$ Full width at halfmaximum (fwhm, $\mathrm{Hz}$ ) given in parentheses. ${ }^{\mathrm{c}} \mathrm{N}$ ot observed. ${ }^{\mathrm{d}}{ }^{13} \mathrm{C}$ $\operatorname{NMR}\left(\mathrm{CDCl}_{3}\right): \delta 239.6,235.3$.

(14.4\%, 10-11 water molecules per $\beta$-CD molecule), the maximum rate of mass loss occurring at $90^{\circ} \mathrm{C}$. There is no further change until $260^{\circ} \mathrm{C}$ when the compound starts to melt and decompose, characterized by an intense, sharp peak in the differential thermogravimetric (DTG) profile at $287^{\circ} \mathrm{C}$. At $500^{\circ} \mathrm{C}, 100 \%$ mass loss is complete. The organometallic $\mathbf{1}$ does not undergo any change until $160{ }^{\circ} \mathrm{C}$ but then decomposes abruptly. A mass loss of $40 \%$ is observed in the temperature range $160-180{ }^{\circ} \mathrm{C}$, with the maximum rate of mass loss occurring at $176^{\circ} \mathrm{C}$. In the case of the mixture, each component behaves independently. Well-defined steps are visible in the TG profile corresponding to the points where the bulk organometallic decomposes (around 182 ${ }^{\circ} \mathrm{C}$ ) and $\beta$-CD melts and decomposes (around $236{ }^{\circ} \mathrm{C}$ ). The lower decomposing point of $\beta$-CD in the mixture compared to that of pure $\beta$-CD is presumably due to the promoting effects of molybdenum on the decomposition of cyclodextrin. In the case of the inclusion compound la, there is no change up to $170{ }^{\circ} \mathrm{C}$ except for gradual loss of hydrated water between 25 and $80{ }^{\circ} \mathrm{C}$. Decomposition occurs above this temperature, characterized by a strong, sharp peak in the DTG profile at $230^{\circ} \mathrm{C}$. Similar TG profiles were obtained for compounds $\mathbf{l a}-$ 4a (see Table 2 for the decomposing points). These results indicate that the molybdenum complexes are thermally more stable in the $\beta$-CD adducts $\mathbf{1 a}-\mathbf{4 a}$ compared to the bulk solids $\mathbf{1 - 4}$, from which it can be inferred that the organometallic molecules in $\mathbf{1 a - 4 a}$ are isolated from each other by at least partial encapsulation in the $\beta$-CD cavities.

Powder XRD. Compounds $\beta-\mathrm{CD} /\left[\mathrm{CpMo}\left(\eta^{4}-\mathrm{C}_{6} \mathrm{H}_{8}\right)-\right.$ $\left.(\mathrm{CO})_{2}\right]\left[\mathrm{BF}_{4}\right]$ (1a) and $\beta$-CD/CpMo $\left(\eta^{3}-\mathrm{C}_{6} \mathrm{H}_{7}\right)(\mathrm{CO})_{2}$ (3a) present similar powder XRD patterns characterized by low angle peaks at about 14.7, 12.2, 9.0, and $7.4 \AA$ (Figure 2). There is no indication for the presence of bulk crystalline organometallic components (1 or $\mathbf{3}$ ), and only a small amount of $\beta$-CD hydrate is present as evidenced by the weak reflections at 8.3 and $7.05 \AA$. Figure 2 al so shows a simulated powder diffraction pattern calculated from the crystal structure data for the 2:1 (host:guest) $\beta$-CD inclusion compound of $\left[\left(\eta^{5}-\mathrm{C}_{5} \mathrm{H}_{5}\right) \mathrm{Fe}\left(\eta^{6}-\mathrm{C}_{6} \mathrm{H}_{5} \mathrm{R}\right)\right]-$ $\left[\mathrm{PF}_{6}\right]\left(\mathrm{R}=\right.$ mesitylene). ${ }^{7 c}$ This compound exhibits the typical channel-type structure consisting of head-tohead dimers of $\beta$-CD molecules stacked along the crystallographic c axis. ${ }^{7 c}$ The exact orientation of the guest molecules could not be determined due to disorder. There is a good match between the calculated pattern 


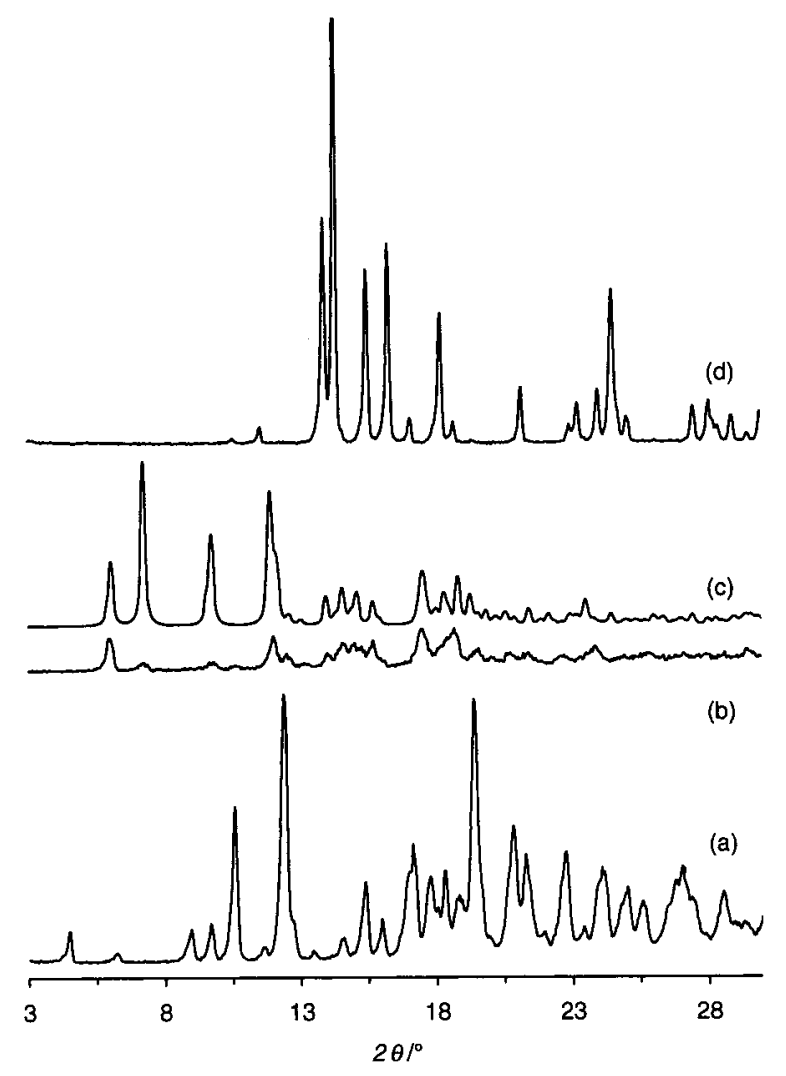

Figure 2. Powder XRD of (a) pristine $\beta$-CD hydrate, (b) $\beta$-CD/[CpM o $\left.\left(\eta^{4}-\mathrm{C}_{6} \mathrm{H}_{8}\right)(\mathrm{CO})_{2}\right]\left[\mathrm{BF}_{4}\right](\mathbf{l a}),(\mathrm{c}) \beta-\mathrm{CD} /\left[\left(\eta^{5}-\mathrm{C}_{5} \mathrm{H}_{5}\right)-\right.$ $\left.\mathrm{Fe}\left(\eta^{6}-\mathrm{C}_{6} \mathrm{H}_{5} \mathrm{R}\right)\right]\left[\mathrm{PF}_{6}\right]\left(\mathrm{R}=\right.$ mesitylene), and (d) $\left[\mathrm{CpMo}\left(\eta^{4}-\right.\right.$ $\left.\left.\mathrm{C}_{6} \mathrm{H}_{8}\right)(\mathrm{CO})_{2}\right]\left[\mathrm{BF}_{4}\right]$ (1). The program PowderCell ${ }^{23}$ was used to produce the simulated pattern (c) from the crystal structure data for the 2:1 inclusion compound formed between $\beta$-CD and $\left[\left(\eta^{5}-\mathrm{C}_{5} \mathrm{H}_{5}\right) \mathrm{Fe}\left(\eta^{6}-\mathrm{C}_{6} \mathrm{H}_{5} \mathrm{R}\right)\right]\left[\mathrm{PF}_{6}\right]{ }^{7 c}$

and the pattern of compound $\mathbf{l a}$, especially at low angles $\left(3-202 \theta^{\circ}\right)$. This implies that the $\beta$-CD adducts $1 \mathbf{a}$ and 3a are channel-type inclusion compounds closely related to those reported by Klingert and Rihs.7c Previous powder XRD studies have shown that $\beta$-CD also forms channel-type inclusion compounds with the molybdenum complexes $\mathrm{C} p^{\prime} \mathrm{Mo}\left(\eta^{3}-\mathrm{C}_{3} \mathrm{H}_{5}\right)(\mathrm{CO})_{2}\left[\mathrm{Cp}^{\prime}=\mathrm{Cp} \text {, Ind }\right]^{12}$ and the [1]ferrocenophane complex $\left[\mathrm{Fe}\left\{\left(\eta^{5}-\mathrm{C}_{5} \mathrm{H}_{4}\right)_{2^{-}}\right.\right.$ $\left.\left.\mathrm{SiMe}_{2}\right\}\right]^{4 h}$

A different result was obtained for compounds $\mathbf{2} \mathbf{a}$ and 4a. These provided powder XRD patterns (not shown) quite similar to that of the host structure. This suggests that the major phase in both samples comprises $\beta$-CD molecules arranged in a herringbone-type pattern, as found in either pristine $\beta$-CD hydrate or $\beta$-CD inclusion compounds with small alcohols. ${ }^{24}$ An additional weak reflection at $12.35 \AA$ may be indicative of a minor phase consisting of a channel-type inclusion compound as described above.

IR Spectroscopy. The KBr IR spectra of compounds $1 a-4 a$ show the typical bands previously reported for bulk $\mathrm{KBr}$ spectra of $\beta$-CD, indicating no chemical modification of the cyclodextrin host. ${ }^{25}$ In addition, some characteristic absorption bands of the guest are observed. The presence of a cis- $\mathrm{M}(\mathrm{CO})_{2}$ unit is clear from

(23) Kraus, W.; N olze, G. J. Appl. Crystallogr. 1996, 29, 301.

(24) Saenger, W.; Steiner, T. Acta Crystallogr. 1998, A54, 798.

(25) Sabapathy, R. C.; Bhattacharyya, S.; Cleland, W. E.; Hussey, C. L. Langmuir 1998, 14, 3797, and literature cited therein. the observed IR data which show, in all cases, two bands in the expected $v(\mathrm{CO})$ stretching region (Table 1 ). These spectra were different from those of the pure organometallics 1-4 in the solid state, which exhibit broader bands probably due to intermolecular interactions $(\mathrm{CH} \cdots \mathrm{O}$ and $\mathrm{CH} \cdots \pi$ contacts, which are known to be present in carbonyl/Cp-containing organometallics $\left.{ }^{26}\right)$. Furthermore, the $v(\mathrm{CO})$ stretching vibrations of the included complexes were shifted by $7-55 \mathrm{~cm}^{-1}$ to higher frequency compared to those of the nonincluded complexes in the solid state. Indeed, the observed frequencies for $\beta$-CD/[CpM o $\left(\eta^{4}-\mathrm{C}_{6} \mathrm{H}_{8}\right)\left(\mathrm{CO}_{2}\right]\left[\mathrm{BF}_{4}\right](\mathbf{l a})$ and $\beta$-CD/ $\mathrm{CpMo}\left(\eta^{3}-\mathrm{C}_{6} \mathrm{H}_{7}\right)(\mathrm{CO})_{2}$ (3a) approach those observed for the corresponding organometallic (1 or $\mathbf{3}$ ) dissolved in dichloromethane (Table 1). These results indicate that the guest complexes are isolated from each other in the cyclodextrin cavities as in solution (a situation that is also suggested by the ab initio calculations, discussed bel ow).

MAS NMR Spectroscopy. The solid-state ${ }^{11} B$ MAS NMR spectra of $\beta$-CD/[CpMo $\left(\eta^{4}-\mathrm{C}_{6} \mathrm{H}_{8}\right)\left(\mathrm{CO}_{2}\right]\left[\mathrm{BF}_{4}\right]$ (1a) and $\beta$-CD/IIndMo $\left.\left(\eta^{4}-\mathrm{C}_{6} \mathrm{H}_{8}\right)(\mathrm{CO})_{2}\right]\left[\mathrm{BF}_{4}\right]$ (2a) contain single peaks at -1.5 and $-1.7 \mathrm{ppm}$, respectively (Table 2 ). The sharp line widths, especially for $\mathbf{l a}$ (full width at halfmaximum, fwhm, ca. $50 \mathrm{~Hz}$ ), imply that boron is in a very symmetrical environment, i.e., tetrahedral $\mathrm{BF}_{4}^{-}$ species. The corresponding resonances for the nonincluded organometallics $\mathbf{1}$ and $\mathbf{2}$ appear downfield relative to those for $\mathbf{1} \mathbf{a}$ and $\mathbf{2} \mathbf{a}$ and are al so significantly broader.

The solid-state ${ }^{13} \mathrm{C}$ CP MAS NMR spectra of $\beta$-CD/ $\left[\mathrm{CpM} \mathrm{o}\left(\eta^{4}-\mathrm{C}_{6} \mathrm{H}_{8}\right)(\mathrm{CO})_{2}\right]\left[\mathrm{BF}_{4}\right](\mathbf{l a})$, the organometallic $\mathbf{1}$, and pristine $\beta$-CD hydrate are shown in Figure 3. The different carbon resonances of $\beta$-CD in $\mathbf{1 a}$ are assigned to C-1 (101-104 ppm), C-4 (78-84 ppm), C-2,3,5 (71$76 \mathrm{ppm})$, and C-6 (59-64 ppm). The existence of multiple resonances for each type of carbon atom is mainly correlated with different torsion angles about the $(1 \rightarrow 4)$ linkages for $C-1$ and C-427,28 and with torsion angles describing the orientation of the hydroxyl groups. ${ }^{29}$ Concerning these resonances, the spectrum of la (Figure $3 c$ ) differs from that of pristine $\beta$-CD hydrate (Figure 3a) in that the resonances for $\mathbf{1 a}$ are broader, becoming almost single peaks for $\mathrm{C}-1$ and $\mathrm{C}-2,3,5$. This is evidence of inclusion of a guest molecule in the $\beta$-CD cavity, as it implies that $\beta$-CD adopts a more symmetrical conformation in the complex 1a, with each glucose unit in a more similar environment. Additional peaks in the spectrum are readily assigned to the resonances of the carbon atoms of the guest molecule. The $\mathrm{Cp}$ and $\eta^{4-}$ coordinated cyclohexadiene groups give rise to peaks at 93.8 (Cp), 86.0, and $24.8\left(\eta^{4}-\mathrm{C}_{6} \mathrm{H}_{8}\right) \mathrm{ppm}$, similar to those observed for pure $\mathbf{1}$. The resonances of the $\mathrm{CO}$ carbons appear as a single peak at $222.2 \mathrm{ppm}$, shifted upfield by $7.5 \mathrm{ppm}$ compared to that for the organometallic $\mathbf{1}$. Comparable results were obtained with $\beta-\mathrm{CD} / \mathrm{CpMo}\left(\eta^{3}\right.$ $\left.\mathrm{C}_{6} \mathrm{H}_{7}\right)(\mathrm{CO})_{2}(3 \mathrm{a})$, for which the ${ }^{13} \mathrm{C}$ resonance of the $\mathrm{Cp}$ group appeared as a single line at $91.4 \mathrm{ppm}$. No well-

(26) Calhorda, M. J . Chem. Commun. 2000, 801.

(27) Gidley, M. J .; Bociek, S. M. J . Am. Chem. Soc. 1988, 110, 3820.

(28) Heyes, S. J .; Clayden, N. J .; Dobson, C. M. Carbohydr. Res. 1992, 233, 1.

(29) Veregin, R. P.; Fyfe, C. A.; Marcessault, R. H.; Tayler, M. G. Carbohydr. Res. 1987, 160, 41. 


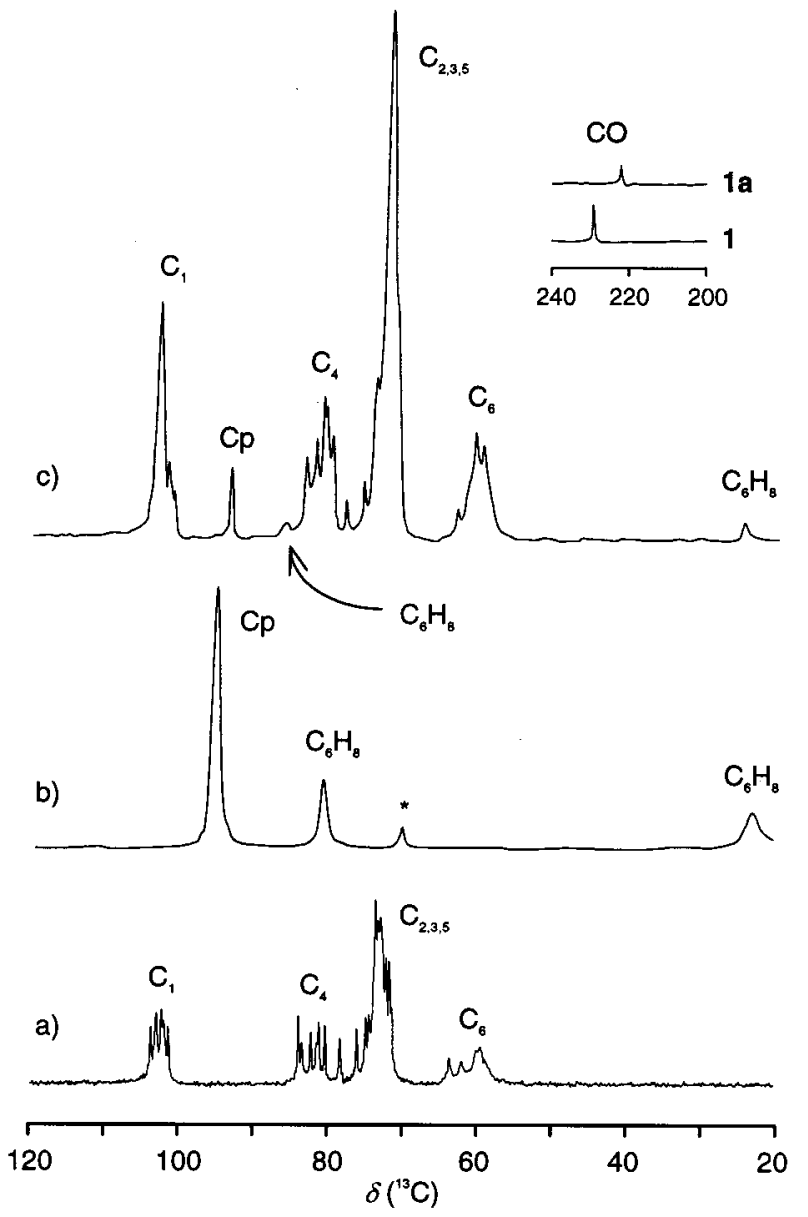

Figure 3. Solid-state ${ }^{13} \mathrm{C} C P$ MAS NMR spectra of (a) $\beta$-CD hydrate, (b) [CpM o $\left(\eta^{4}-\mathrm{C}_{6} \mathrm{H}_{8}\right)\left(\mathrm{CO}_{2}\right]\left[\mathrm{BF}_{4}\right](\mathbf{1})$, and (c) $\beta$-CD/[CpMo $\left.\left(\eta{ }^{4}-\mathrm{C}_{6} \mathrm{H}_{8}\right)(\mathrm{CO})_{2}\right]\left[\mathrm{BF}_{4}\right]$ (1a). An asterisk denotes a spinning side band.

defined line could however be discerned for the resonances of the $\mathrm{CO}$ carbons.

In the ${ }^{13} \mathrm{C} C P$ MAS NMR spectra of $\beta$-CD/[I ndMo( $\eta^{4}$ $\left.\left.\mathrm{C}_{6} \mathrm{H}_{8}\right)(\mathrm{CO})_{2}\right]\left[\mathrm{BF}_{4}\right](\mathbf{2 a})$ and $\beta-\mathrm{CD} / \mathrm{IndM} \mathrm{o}\left(\eta^{3}-\mathrm{C}_{6} \mathrm{H}_{7}\right)(\mathrm{CO})_{2}$ (4a), each carbon resonance of $\beta$-CD shows multiple peaks with a higher resolution than that found for $\mathbf{l a}$ and $\mathbf{3 a}$. Indeed, the spectra of $\mathbf{2} \mathbf{a}$ and $\mathbf{4 a}$ are quite similar to that previously reported for pristine $\beta-C D$ hydrate, ${ }^{28}$ indicating that the macrocyclic conformations are comparable. The organometallic components in $\mathbf{2 a}$ and $\mathbf{4 a}$ give rise to only very weak peaks relative to those of cyclodextrin, as expected from the low guest: host ratio.

3. Ab Initio Calculations. Ab initio calculations for the organometallics 1-4 yielded molecular structures in agreement with the available X-ray data for similar systems. ${ }^{30}$ The presence of a single hapticity conformer experimentally observed for $\mathbf{4}$ is al so predicted from the cal culations since the structures with $\eta^{3}$-indenyl al ways slip to $\eta^{5}$-indenyl during geometry optimization.

An interesting feature is revealed by the calculated vibrational spectra: while the observed wavenumbers of the ring ligands are generally well predicted for the organometal lics, the cal culated scaled wavenumbers of

(30) Azevedo, C. G. de; Calhorda, M. J .; Carrondo, M. A. A. F. d. C. T.; Dias, A. R.; Duarte, M. T.; Galvão, A. M.; Gamelas, C. A.; Gonçalves, I. S.; Piedade, F. M. da; Romão, C. C. J . Organomet. Chem. 1997, 544, 257.
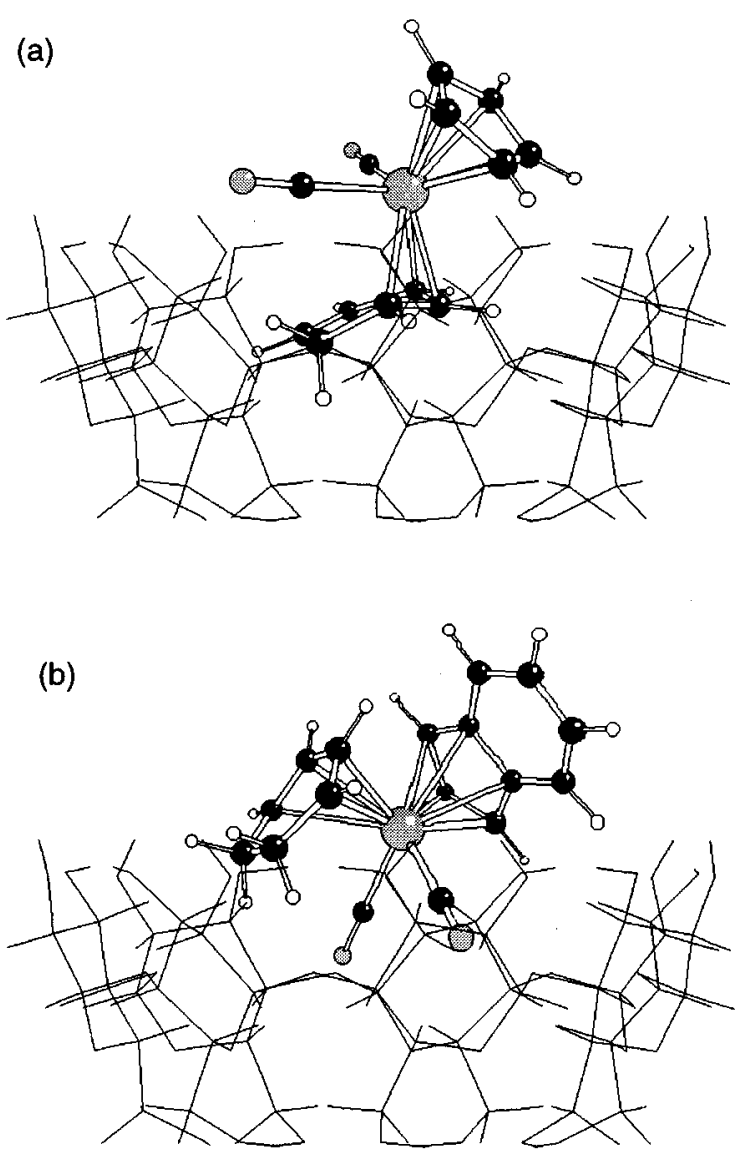

Figure 4. Schematic representation of the lowest energy structures found for the indusion compounds (a) $\beta$-CD/ $\mathrm{CpMo}\left(\eta^{3}-\mathrm{C}_{6} \mathrm{H}_{7}\right)(\mathrm{CO})_{2}$ (3a) and (b) $\beta$-CD/[IndM o $\left(\eta^{4}-\mathrm{C}_{6} \mathrm{H}_{8}\right)-$ $\left.(\mathrm{CO})_{2}\right]\left[\mathrm{BF}_{4}\right](2 \mathrm{a})$.

the carbonyl ligands stretching modes are blue-shifted, approaching the experimental values for the inclusion compounds (Table 1). Since the ab initio calculations refer to the isolated molecule, this observation supports the presence of intermolecular interactions involving the carbonyl groups in the crystalline solids 1-4 and the absence of such interactions in the inclusion compounds.

For the $\eta^{5}$-cyclopentadienyl analogues $\mathbf{1}$ and $\mathbf{3}$, the best organometallic- $\beta$-CD interaction geometry was found to be with the C6-ring ligand inside the cavity, as shown in Figure 4a. Such geometry al lows the partial inclusion of the remaining ligands in the cavity of a second CD, yielding a channel-type structure, with a head-to-head arrangement of the CDs, as previously found for similar systems with 2:1 stoichiometry. ${ }^{7 \mathrm{c}}$ It should be mentioned that the interaction geometries allowing hydrogen bonding between the carbonyl ligands and the hydroxyl groups of the CD have been tested but were not found among the most stable ones at this level of calculation.

In what concerns the organometallics $\mathbf{2}$ and $\mathbf{4}$, the presence of the indenyl ligand (instead of $\mathrm{Cp}$ ) reduces the stability of a similar inclusion geometry (due to the steric hindrance between Ind and the rim of $C D$ ). The lowest energy organometallic $-\beta-C D$ geometry found presents the two carbonyl ligands inside the CD cavity [Figure 4b]. This geometry, however, is not favorable to the approach of a second CD due to the orientation of the indenyl ligand. Nevertheless, the inclusion inside the cavities of two head-to-head CDs is possible with 
less stable organometallic- $\beta$-CD interaction geometries. Although it is not possible from these calculations to decide on the 2:1 or 1:1 stoichiometry of the inclusion compounds of $\mathbf{2}$ and $\mathbf{4}$, the steric hindrance arising from the presence of the indenyl ligand seems to be a possible explanation for the experimentally observed lower stability of these compounds relative to the inclusion compounds of $\mathbf{1}$ and $\mathbf{3}$.

\section{Conclusion}

We have shown that $\beta$-cyclodextrin forms stable 2:1 channel-type inclusion compounds selectively with the dicarbonyl complexes [CpMo $\left(\eta^{4}-\mathrm{C}_{6} \mathrm{H}_{8}\right)\left(\mathrm{CO}_{2}\right]\left[\mathrm{BF}_{4}\right]$ and $\mathrm{CpMo}\left(\eta^{3}-\mathrm{C}_{6} \mathrm{H}_{7}\right)(\mathrm{CO})_{2}$. Less stable $\beta$-CD adducts are formed with the corresponding indenyl analogues of these molybdenum complexes. The ab initio calculations provide valuable insight into the possible inclusion geometries and hence the relative stabilities of the cycl odextrin complexes. Organometal lic complexes such as the 18-electron cation $\left[\mathrm{CpMo}\left(\eta^{4}-\mathrm{C}_{6} \mathrm{H}_{8}\right)(\mathrm{CO})_{2}\right]^{+}$are of considerable interest in organic synthesis because they undergo sequential ster eospecific nucl eophilic additions on the coordinated diene. It should be of interest to study this reaction chemistry when the complexes are encapsulated within a chiral host molecule, in this case $\beta$-cyclodextrin. Although the cyclodextrin complexes are insoluble in common organic solvents, the possibility of carrying out heterogeneous reactions cannot be ruled out. These studies are in progress in our laboratories.

\section{Experimental Section}

General Methods and Procedures. All air-sensitive reactions and manipulations were performed using standard Schlenk techniques under an oxygen-free and water-free nitrogen atmosphere. Solvents were dried by standard procedures (THF and $\mathrm{Et}_{2} \mathrm{O}$ over $\mathrm{Na} /$ benzophenone ketyl; $\mathrm{CH}_{2} \mathrm{Cl}_{2}$ and NCMe over $\mathrm{CaH}_{2}$ ), distilled under nitrogen, and kept over 4 $\AA$ molecular sieves ( $3 \AA$ for NCMe). $\beta$-CD was obtained from Wacker Chemie (München) and recrystallized before use.

Microanalyses were performed at the TU Munich by $M$. Barth and co-workers. Infrared spectra were recorded on a Unican Mattson Mod 7000 FTIR spectrophotometer in solution $\left(\mathrm{CH}_{2} \mathrm{Cl}_{2}\right)$ or as $\mathrm{KBr}$ pellets. TGA studies were performed using a Mettler TA3000 system at a heating rate of $5 \mathrm{~K} / \mathrm{min}$ under a static atmosphere of air. Powder XRD data were collected on a Philips X'pert diffractometer using $\mathrm{Cu} \mathrm{K} \alpha$ radiation filtered by $\mathrm{Ni}(\lambda=1.5418 \AA)$. ${ }^{1} \mathrm{H}$ NMR spectra were measured in solution using a Bruker CXP 300 spectrometer. Roomtemperature solid-state ${ }^{11} \mathrm{~B}$ and ${ }^{13} \mathrm{C}$ NMR spectra were recorded at 128.4 and $100.6 \mathrm{MHz}$, respectively, on a (9.4 T) Bruker MSL 400P spectrometer. ${ }^{11} \mathrm{~B}$ MAS NMR spectra were recorded with short $0.6 \mu \mathrm{s}\left(15^{\circ}\right)$ pulses, spinning rates of $7 \mathrm{kHz}$, and $2 \mathrm{~s}$ recycle delays. Chemical shifts are quoted in parts per million from $\left(\mathrm{C}_{2} \mathrm{H}_{5} \mathrm{O}\right)_{2} \mathrm{OBF}_{3} \cdot{ }^{13} \mathrm{C} \mathrm{CP}$ MAS NMR spectra were recorded with a $4.5 \mu \mathrm{s}^{1} \mathrm{H} 90^{\circ}$ pulse, 2 ms contact time, a spinning rate of $9 \mathrm{kHz}$, and $7 \mathrm{~s}$ recycle delays. Chemical shifts are quoted in parts per million from TMS.

General Preparation of $\left[\mathrm{Cp}^{\prime} \mathrm{Mo}\left(\eta^{4}-\mathrm{C}_{6} \mathrm{H}_{8}\right)(\mathrm{CO})_{2}\right]\left[\mathrm{BF}_{4}\right]$ $\left[\mathbf{C} \mathbf{p}^{\prime}=\mathbf{C p}\right.$ (1), Ind (2)]. A solution of $\mathrm{Cp}^{\prime} \mathrm{Mo}\left(\eta^{3}-\mathrm{C}_{3} \mathrm{H}_{5}\right)(\mathrm{CO})_{2}{ }^{19 g}$ $(1.0 \mathrm{~g})$ in $\mathrm{CH}_{2} \mathrm{Cl}_{2}(30 \mathrm{~mL})$ was treated with 1 equiv of $\mathrm{HBF}_{4}$. $\mathrm{Et}_{2} \mathrm{O}$. After $15 \mathrm{~min}$, excess 1,3 -cyclohexadiene $(3 \mathrm{~mL})$ was added and the reaction mixture was allowed to stand for $3 \mathrm{~h}$. After concentration to ca. $10 \mathrm{~mL}$ and addition of a mixture of hexane/Et $t_{2} \mathrm{O}$, the yellow precipitate formed was recovered by filtration and washed with diethyl ether.

[CpMo( $\left.\eta^{4}-\mathbf{C}_{6} \mathbf{H}_{8}\right)\left(\mathrm{CO}_{2}\right)_{[}\left[\mathrm{BF}_{4}\right]$ (1). IR and ${ }^{1} \mathrm{H}$ NMR data were in agreement with those in refs 18 and $19 \mathrm{~g} .{ }^{13} \mathrm{C}$ CP MAS
NMR: $\delta 229.7$ (s, CO), 95.7 (s, Cp), $81.0\left(\mathrm{~s}, \mathrm{C}_{6} \mathrm{H}_{8}\right.$ ), 23.6 (s, $\left.\mathrm{C}_{6} \mathrm{H}_{8}\right) .{ }^{11} \mathrm{~B}$ MAS NMR: $\delta-1.4(\mathrm{~s})$

[IndMo $\left(\eta^{4}-\mathbf{C}_{6} \mathbf{H}_{8}\right)\left(\mathrm{CO}_{2}\right]\left[\mathrm{BF}_{4}\right]$ (2). Recrystallization from $\mathrm{CH}_{2} \mathrm{Cl}_{2} / \mathrm{Et}_{2} \mathrm{O}$. Y ield: $1.3 \mathrm{~g}(92 \%)$. Elemental analysis (EA) and ${ }^{1} \mathrm{H}$ NMR data were in agreement with those in ref 21 . Selected IR ( $\left.\mathrm{KBr}, \mathrm{cm}^{-1}\right)$ : $3074 \mathrm{~m}, 1999$ vs $(v(\mathrm{CO})), 1941$ vs $(v(\mathrm{CO})), 1448$ m, 1339 m, 1083 vs, 1031 vs, 872 m, 766 s, 579 m, 534 m, 507 m, 449 m. ${ }^{13} \mathrm{C}$ CP MAS NMR: $\delta 229.9$ (s, CO), 132.4, 127.8, 122.3, 115.2, 108.7 (Ind), 93.8 (br, $\left.\mathrm{C}_{6} \mathrm{H}_{8}\right), 84.7,78.3$ (Ind), 25.1 (s, $\mathrm{C}_{6} \mathrm{H}_{8}$ ). ${ }^{11} \mathrm{~B}$ MAS NMR: $\delta-1.0(\mathrm{~s})$.

General Preparation of $\mathrm{Cp}^{\prime} \mathrm{Mo}\left(\eta^{3}-\mathrm{C}_{6} \mathrm{H}_{7}\right)(\mathrm{CO})_{2}\left[\mathrm{Cp}^{\prime}=\mathrm{Cp}\right.$ (3), Ind (4)]. A solution of [Cp'Mo $\left.\left(\eta^{4}-\mathrm{C}_{6} \mathrm{H}_{8}\right)(\mathrm{CO})_{2}\right]\left[\mathrm{BF}_{4}\right](1.0 \mathrm{~g})$ in $\mathrm{CH}_{2} \mathrm{Cl}_{2}$ (30 mL) was treated with excess $\mathrm{NEt}_{3}(1 \mathrm{~mL})$ for 1 $h$. The resulting reaction mixture was then evaporated to dryness, and the residue extracted with hexane. After being concentrated and cooled, the yellow crystalline complex was isol ated.

$\mathrm{CpMo}\left(\eta^{3}-\mathrm{C}_{6} \mathbf{H}_{7}\right)(\mathbf{C O})_{2}$ (3). EA and ${ }^{1} \mathrm{H}$ NMR data were in agreement with those of ref $17 \mathrm{~d} .{ }^{13} \mathrm{C}$ CP MAS NMR: $\delta 237.0$ (br, CO), 132.1 (br, $\left.\mathrm{C}_{6} \mathrm{H}_{7}\right), 116.9\left(\mathrm{~d}, \mathrm{C}_{6} \mathrm{H}_{7}\right), 92.3(\mathrm{~s}, \mathrm{Cp}), 60.3$ $\left(\mathrm{br}, \mathrm{C}_{6} \mathrm{H}_{7}\right), 52.1\left(\mathrm{br}, \mathrm{C}_{6} \mathrm{H}_{7}\right), 40.5\left(\mathrm{br}, \mathrm{C}_{6} \mathrm{H}_{7}\right), 28.2\left(\mathrm{br}, \mathrm{C}_{6} \mathrm{H}_{7}\right)$.

IndMo $\left(\boldsymbol{\eta}^{\mathbf{3}}-\mathbf{C}_{\mathbf{6}} \mathbf{H}_{\mathbf{7}}\right)(\mathbf{C O})_{\mathbf{2}}$ (4). Recrystallization from hexane/ $\mathrm{Et}_{2} \mathrm{O}$. Yield: $0.72 \mathrm{~g}(90 \%)$. Found: C, 58.69; H, 3.98. Anal. Calcd for $\mathrm{C}_{17} \mathrm{H}_{14} \mathrm{O}_{2} \mathrm{Mo}$ (346.24): C, 58.97; $\mathrm{H}, 4.08$. IR $(\mathrm{KBr}$, $\left.\mathrm{cm}^{-1}\right): 3198 \mathrm{~m}, 1932$ vs ( $\left.(\mathrm{CO})\right), 1839$ vs $(v(\mathrm{CO})), 1443 \mathrm{~m}, 1423$ m, 1389 m, 1337 m, 818 s, 749 s, 716 s, 630 s, 574 s, 485 s, $460 \mathrm{~m} .{ }^{1 \mathrm{H}} \mathrm{NMR}\left(\mathrm{CDCl}_{3}, 300 \mathrm{MHz}, 25^{\circ} \mathrm{C}\right): \delta 7.05\left(\mathrm{~s}, 4 \mathrm{H}, \mathrm{H}_{5-8}\right)$, 6.01 and $5.87\left(2 \mathrm{~s}, 1 \mathrm{H}\right.$ each, $\mathrm{H}_{1}$ and $\left.\mathrm{H}_{3}\right), 5.53\left(\mathrm{t}, 1 \mathrm{H}, \mathrm{H}_{2}\right), 5.97-$ $5.89(\mathrm{~m}, 1 \mathrm{H}), 4.50-4.47(\mathrm{~m}, 1 \mathrm{H}), 3.49-3.43(\mathrm{~m}, 3 \mathrm{H})$ and 2.39 $2.37(\mathrm{~m}, 2 \mathrm{H})$, together $7 \mathrm{H}\left(\mathrm{C}_{6} \mathrm{H}_{7}\right) \cdot{ }^{13} \mathrm{C} \mathrm{CP}$ MAS NMR: $\delta 240.5$ (s, CO), 132.3 (d, $\left.\mathrm{C}_{6} \mathrm{H}_{7}\right), 124.4$ (s, Ind), 119.2 (br, $\left.\mathrm{C}_{6} \mathrm{H}_{7}\right), 111.7$ (br, Ind), 89.5 (s, Ind), 80.5 (s, $\left.\mathrm{C}_{6} \mathrm{H}_{7}\right), 75.8$ (s, Ind), 65.1, 58.5, $29.7\left(\mathrm{br}, \mathrm{C}_{6} \mathrm{H}_{7}\right)$.

Preparation of $\beta-\mathrm{CD} /\left[\mathrm{CpMo}\left(\eta^{4}-\mathrm{C}_{6} \mathrm{H}_{8}\right)(\mathrm{CO})_{2}\right]\left[\mathrm{BF}{ }_{4}\right]$ (1a). A solution of $\beta$-CD hydrate $(0.34 \mathrm{~g}, 0.30 \mathrm{mmol})$ in water $(4.5$ $\mathrm{mL})$ was treated with a solution of $\left[\mathrm{CpMo}\left(\eta^{4}-\mathrm{C}_{6} \mathrm{H}_{8}\right)(\mathrm{CO})_{2}\right]\left[\mathrm{BF}_{4}\right]$ $(0.05 \mathrm{~g}, 0.13 \mathrm{mmol})$ in $\mathrm{CH}_{2} \mathrm{Cl}_{2}(3 \mathrm{~mL})$ and the mixture kept at $60{ }^{\circ} \mathrm{C}$ for $2 \mathrm{~h}$. After evaporation of the $\mathrm{CH}_{2} \mathrm{Cl}_{2}$ and addition of ethanol $(2 \mathrm{~mL})$, the mixture was stirred for $24 \mathrm{~h}$ at room temperature. The suspension was filtered and the pale yellow powder washed several times with $\mathrm{CH}_{2} \mathrm{Cl}_{2}$ and water and vacuum-dried. Yield: $0.23 \mathrm{~g}$ (62\%). Found: $\mathrm{C}, 40.43 ; \mathrm{H}, 6.20$; $\mathrm{Mo}$, 3.49. Anal. Calcd for $\left(\mathrm{C}_{13} \mathrm{H}_{13} \mathrm{O}_{2} \mathrm{BF}_{4} \mathrm{Mo}\right) \cdot 2\left(\mathrm{C}_{42} \mathrm{H}_{70} \mathrm{O}_{35}\right) \cdot$ $12 \mathrm{H}_{2} \mathrm{O}: \mathrm{C}, 40.59 ; \mathrm{H}, 6.22 ; \mathrm{Mo}, 3.34$. IR $\left(\mathrm{KBr}, \mathrm{cm}^{-1}\right): 3381$ vs, 2924 s, 2017 vs ( $v(C O))$, 1863 vs ( $v(C O)), 1417 \mathrm{~m}, 1368 \mathrm{~m}, 1334$ m, 1157 vs, 1083 vs, 1029 vs, 938 s, 861 m, 755 m, 704 m, 608 $\mathrm{m}, 575 \mathrm{~s}, 529 \mathrm{~m}, 446 \mathrm{~m}, 363 \mathrm{~m} .{ }^{13} \mathrm{C}$ CP MAS NMR: $\delta 222.2$ (s, CO), 103.7, 102.3, $101.5(\beta-\mathrm{CD}, \mathrm{C}-1), 93.8(\mathrm{~s}, \mathrm{Cp}), 85.9(\mathrm{br}$, $\left.\mathrm{C}_{6} \mathrm{H}_{8}\right), 83.7,82.8,82.3,81.5,80.8,78.3(\beta-\mathrm{CD}, \mathrm{C}-4), 75.9,74.5$, 73.0 ( $\beta$-CD, C-2,3,5), 63.5, 61.9, 61.1, 59.9 ( $\beta$-CD, C-6), 24.8 (s, $\left.\mathrm{C}_{6} \mathrm{H}_{8}\right) .{ }^{11} \mathrm{~B}$ MAS NMR: $\delta-1.5(\mathrm{~s})$.

Reaction of $\beta$-CD with [IndMo $\left.\left(\eta^{4}-\mathrm{C}_{6} \mathrm{H}_{8}\right)(\mathrm{CO})_{2}\right]\left[B \mathrm{~F}_{4}\right]$ (2a). A solution of $\beta$-CD $(0.61 \mathrm{~g}, 0.54 \mathrm{mmol})$ in water $(8.2 \mathrm{~mL})$ was treated with a solution of $\left[\mathrm{IndM} \mathrm{o}\left(\eta^{4}-\mathrm{C}_{6} \mathrm{H}_{8}\right)(\mathrm{CO})_{2}\right]\left[\mathrm{BF}_{4}\right](0.1$ $\mathrm{g}, 0.23 \mathrm{mmol}$ ) in $\mathrm{CH}_{2} \mathrm{Cl}_{2}(5.8 \mathrm{~mL})$, and the mixture was kept at $60{ }^{\circ} \mathrm{C}$ for $48 \mathrm{~h}$. After evaporation of the $\mathrm{CH}_{2} \mathrm{Cl}_{2}$, the suspension was filtered and the pale yellow powder washed several times with $\mathrm{CH}_{2} \mathrm{Cl}_{2}$ and water and vacuum-dried. Found: $\mathrm{C}, 41.00 ; \mathrm{H}, 6.23$; Mo, 1.45. Anal. Calcd for $\left(\mathrm{C}_{17} \mathrm{H}_{15} \mathrm{O}_{2^{-}}\right.$ $\left.\mathrm{BF}_{4} \mathrm{Mo}\right) \cdot 2\left(\mathrm{C}_{42} \mathrm{H}_{70} \mathrm{O}_{35}\right) \cdot 12 \mathrm{H}_{2} \mathrm{O}: \mathrm{C}, 41.54 ; \mathrm{H}, 6.18 ; \mathrm{Mo}, 3.29$. IR $\left(\mathrm{KBr}, \mathrm{cm}^{-1}\right): 3375 \mathrm{vs}, 2925 \mathrm{~s}, 2044$ vs $(v(\mathrm{CO})), 1997$ vs $(v(\mathrm{CO}))$, 1415 m, 1368 m, 1334 m, 1157 vs, 1080 vs, 1029 vs, 860 m, $755 \mathrm{~m}, 706 \mathrm{~m}, 608 \mathrm{~m}, 577 \mathrm{~s}, 531 \mathrm{~m}, 435 \mathrm{~m}, 363 \mathrm{~m} .{ }^{13} \mathrm{C} \mathrm{CP}$ MAS NMR: $\delta 121.8,119.2,110.3$ (Ind), 103.7, 103.1, 102.3, 101.5 ( $\beta$-CD, C-1), 90.2 (br, $\mathrm{C}_{6} \mathrm{H}_{8}$ ), 86.2, 81.8 (Ind), 83.9, 83.3, 82.1, 80.2, 80.2, 78.1 ( $\beta$-CD, C-4), 75.9, 74.8, 73.0, 72.1, 71.6 $(\beta-\mathrm{CD}, \mathrm{C}-2,3,5), 63.5,61.9,59.9,59.3(\beta-\mathrm{CD}, \mathrm{C}-6), 24.8(\mathrm{br}$, $\mathrm{C}_{6} \mathrm{H}_{8}$ ). ${ }^{11}$ B MAS NMR: $\delta-1.7(\mathrm{~s})$.

Preparation of $\beta-\mathrm{CD} / \mathrm{CpMo}\left(\eta^{3}-\mathrm{C}_{6} \mathrm{H}_{7}\right)(\mathrm{CO})_{2}$ (3a). A solution of $\beta$-CD $(0.77 \mathrm{~g}, 0.68 \mathrm{mmol})$ in water $(18 \mathrm{~mL})$ was treated with a solution of $\mathrm{CpMo}\left(\eta^{3}-\mathrm{C}_{6} \mathrm{H}_{7}\right)(\mathrm{CO})_{2}(0.1 \mathrm{~g}, 0.34 \mathrm{mmol})$ in 
$\mathrm{CH}_{2} \mathrm{Cl}_{2}(14 \mathrm{~mL})$, and the mixture was kept at $40{ }^{\circ} \mathrm{C}$ for $8 \mathrm{~h}$. After evaporation of the $\mathrm{CH}_{2} \mathrm{Cl}_{2}$, the suspension was filtered and the pale yellow powder washed several times with $\mathrm{CH}_{2-}$ $\mathrm{Cl}_{2}$ and water and vacuum-dried. Yield: $0.43 \mathrm{~g}(45 \%)$. Found: $\mathrm{C}$, 41.08; $\mathrm{H}, 6.35$; $\mathrm{Mo}, 3.26$. Anal. Calcd for $\left(\mathrm{C}_{13} \mathrm{H}_{12} \mathrm{O}_{2} \mathrm{Mo}\right)$. $2\left(\mathrm{C}_{42} \mathrm{H}_{70} \mathrm{O}_{35}\right) \cdot 14 \mathrm{H}_{2} \mathrm{O}: \mathrm{C}, 41.33 ; \mathrm{H}, 6.44 ; \mathrm{Mo}, 3.40$. IR $(\mathrm{KBr}$, $\left.\mathrm{cm}^{-1}\right): 3382$ vs, $2923 \mathrm{~s}, 1940$ vs ( $\left.v(\mathrm{CO})\right), 1865$ vs $(v(\mathrm{CO})), 1642$ s, 1415 m, 1368 m, 1334 m, 1157 vs, 1083 vs, 1029 vs, 861 m, $755 \mathrm{~m}, 706 \mathrm{~m}, 609 \mathrm{~m}, 576 \mathrm{~s}, 530 \mathrm{~m}, 405 \mathrm{~m}, 362 \mathrm{~m} .{ }^{13} \mathrm{C} \mathrm{CP}$ MAS NMR: $\delta 128.1\left(\mathrm{br}, \mathrm{C}_{6} \mathrm{H}_{7}\right), 113.6\left(\mathrm{br}, \mathrm{C}_{6} \mathrm{H}_{7}\right), 103.2,102.2$, $(\beta-\mathrm{CD}, \mathrm{C}-1), 91.4$ (s, Cp), 83.6, 81.2, 80.2, 78.3 ( $\beta$-CD, C-4), 72.9 $(\beta-\mathrm{CD}, \mathrm{C}-2,3,5), 63.3,61.8,59.9(\beta-\mathrm{CD}, \mathrm{C}-6), 52.6\left(\mathrm{br}, \mathrm{C}_{6} \mathrm{H}_{7}\right)$, $41.2\left(\mathrm{br}, \mathrm{C}_{6} \mathrm{H}_{7}\right), 29.1\left(\mathrm{br}, \mathrm{C}_{6} \mathrm{H}_{7}\right)$.

Reaction of $\beta$-CD with IndMo $\left(\eta^{3}-C_{6} \mathrm{H}_{7}\right)(\mathrm{CO})_{2}$ (4a). A solution of $\beta$-CD $(0.66 \mathrm{~g}, 0.58 \mathrm{mmol})$ in water $(12.5 \mathrm{~mL})$ was treated with a solution of IndMo $\left(\eta^{3}-\mathrm{C}_{6} \mathrm{H}_{7}\right)(\mathrm{CO})_{2}(0.1 \mathrm{~g}, 0.29$ $\mathrm{mmol})$ in $\mathrm{CH}_{2} \mathrm{Cl}_{2}(5.8 \mathrm{~mL})$, and the mixture was kept at $50{ }^{\circ} \mathrm{C}$ for $48 \mathrm{~h}$. After evaporation of the $\mathrm{CH}_{2} \mathrm{Cl}_{2}$, the suspension was filtered and the pale yell ow powder washed several times with $\mathrm{CH}_{2} \mathrm{Cl}_{2}$ and water and vacuum-dried. Found: $\mathrm{C}, 40.42 ; \mathrm{H}, 6.51$; $\mathrm{Mo}, 1.81$. Anal. Calcd for $\left(\mathrm{C}_{17} \mathrm{H}_{14} \mathrm{O}_{2} \mathrm{Mo}\right) \cdot 2\left(\mathrm{C}_{42} \mathrm{H}_{70} \mathrm{O}_{35}\right) \cdot 12 \mathrm{H}_{2} \mathrm{O}$ : C, 42.83; H, 6.33; Mo, 3.39. IR ( $\left.\mathrm{KBr}, \mathrm{cm}^{-1}\right): 3396 \mathrm{vs}, 2924 \mathrm{~s}$, 1940 vs $(v(\mathrm{CO})), 1869$ vs $(v(\mathrm{CO})), 1415 \mathrm{~m}, 1368 \mathrm{~m}, 1335 \mathrm{~m}$, 1157 vs, 1083 vs, 1029 vs, 861 m, 755 m, 706 m, 608 m, 575 s, $529 \mathrm{~m}, 406 \mathrm{~m}, 361 \mathrm{~m} .{ }^{13} \mathrm{C}$ CP MAS NMR: $\delta 128.6-120.3(\mathrm{br}$, $\left.\mathrm{C}_{6} \mathrm{H}_{7}+\mathrm{Ind}\right), 113.8$ (Ind), 103.0, 102.5, $101.4(\beta-\mathrm{CD}, \mathrm{C}-1), 90.2$ $\left(\mathrm{C}_{6} \mathrm{H}_{7} / \mathrm{lnd}\right), 84.0,81.2,78.1\left(\beta-\mathrm{CD}, \mathrm{C}-4 / \mathrm{C}_{6} \mathrm{H}_{7}\right), 76.0,72.8,(\beta-$ $\mathrm{CD}, \mathrm{C}-2,3,5 / \mathrm{lnd}), 63.5,60.1,\left(\beta-\mathrm{CD}, \mathrm{C}-6 / \mathrm{C}_{6} \mathrm{H}_{7}\right), 30.2\left(\mathrm{br}, \mathrm{C}_{6} \mathrm{H}_{7}\right)$.

Ab Initio Calculations. Ab initio calculations were performed using the $\mathrm{G} 98$ w program package ${ }^{31}$ running on a personal computer (Pentium 400, 320 MB RAM). For the free organometallics, the geometry was fully optimized at the HF and B $3 L$ YP levels using the Dunning/H uzinaga valence double $\xi$ basis set for the first period elements ${ }^{32}$ and the Effective Core Potentials of $\mathrm{H}$ ay and Wadt with double- $\zeta$ splitting $^{33}$ for the Mo atom, as implemented in G98 (LanL2DZ option). $\mathrm{H}$ armonic vibrational frequencies were calculated at the HF/
LanL2DZ level, using analytic second derivatives. For comparison with the experimental values, the large size of the system required a different approach and the calculated wavenumbers were scaled by the standard factor of $0.89 .{ }^{34}$

In what concerns the inclusion compounds, several possible inclusion geometries were tested by single-point calculations using the two-layer approximation of Morokuma et al. ${ }^{35}$ as implemented in G98 (ONIOM keyword). The organometallics were treated at high layer, using the effective core potentials described above (HF/LanL 2DZ) while the $\beta$-CD was set as the low layer and optimized at the semiempirical AM1 level. ${ }^{36}$

Acknowledgment. We are grateful to PRAXIS XXI for funding.

\section{OM001088S}

(31) Frisch, M. J .; Trucks, G. W.; Schlegel, H. B.; Scuseria, G. E.; Robb, M. A.; Cheeseman, J . R.; Zakrzewski, V. G.; Montgomery, J . A.; Stratmann, R. E.; Burant, J . C.; Dapprich, S.; Millam, J . M.; Daniels, A. D.; Kudin, K. N.; Strain, M. C.; Farkas, O.; Tomasi, J .; Barone, V.; Cossi, M.; Cammi, R.; Mennucci, B.; Pomelli, C.; Adamo, C.; Clifford, S.; Ochterski, J .; Petersson, G. A.; Ayala, P. Y.; Cui, Q.; Morokuma, K.; Malick, D. K.; Rabuck, A. D.; Raghavachari, K.; Foresman, J. B.; Cioslowski, J .; Ortiz, J . V.; Stefanov, B. B.; Liu, G.; Liashenko, A.; Piskorz, P.; Komaromi, I.; Gomperts, R.; Martin, R. L.; Fox, D. J .; Keith T.; Al-Laham, M. A.; Peng, C. Y.; Nanayakkara, A.; Gonzalez, C.; Challacombe, M.; Gill, P. M. W.; J ohnson, B. G.; Chen, W.; Wong, M. W.; Andres, J. L.; Head-Gordon, M.; Replogle, E. S.; Pople, J. A.; Gaussian 98 (Revision A.1); Gaussian, Inc.: Pittsburgh, PA, 1998.

(32) Dunning, T. H., J r.; Hay, P.J . In Modern Theoretical Chemistry; Schaefer, H. F., Ed.; Plenum: New York, 1976; Vol. 3, p1

(33) Wadt, W. R.; Hay, P. J . J . Chem. Phys. 1985, 82, 284

(34) Heyne, W. J .; Radom, L.: Pople, J. A.; Schleyer, P. R. Ab Initio Molecular Orbital Theory; Wiley: New York, 1986.

(35) (a) Humbel, S.; Sieber, S.; Morokuma, K. J . Chem. Phys. 1996 105, 1959. (b) Matsubara, T.; Sieber, S.; Morokuma, K. J . Quantum Chem. 1996, 60, 1101. (c) Svensson, M.; Humbel, S.; Froese, R. D. J .; Matsubara, T.; Sieber, S.; Morokuma, K. J . Phys. Chem. 1996, 100, 19357. 140.

(36) Dewar, M. J . S.; Reynolds, C. H. J . Comput. Chem. 1986, 2, 